\title{
Active Tectonic Strike-Slip Fault Development near Goran, Samba and Kathua Districts, Jammu and Kashmir
}

\author{
Vikram Sharma, A. R. Chaudhri \\ Department of Geology, Kurukshetra University, Kurukshetra, India \\ Email: archaudhri@gmail.com
}

How to cite this paper: Sharma, V. and Chaudhri, A.R. (2020) Active Tectonic Strike-Slip Fault Development near Goran, Samba and Kathua Districts, Jammu and Kashmir. Open Journal of Geology, 10, 301-316.

https://doi.org/10.4236/ojg.2020.104016

Received: February 17, 2020

Accepted: April 5, 2020

Published: April 8, 2020

Copyright $\odot 2020$ by author(s) and Scientific Research Publishing Inc. This work is licensed under the Creative Commons Attribution International License (CC BY 4.0).

http://creativecommons.org/licenses/by/4.0/

\begin{abstract}
Active tectonic morphometric studies of the sparsely investigated frontal $\mathrm{Si}$ walik terrain around Goran in the Samba district bordering the Kathua district of J\&K reveal the presence of NW-SE trending active sinistral strike-slip fault with oblique slip component which is parallel to the Surin-Masatgarh anticline. The Basantar River, the Tarnah stream, the Ujh River, the Sahaar stream and the Ravi River exhibit significant stream offsets where the fault crosses these channels. The values of the morphometric indices viz. stream sinuosity index $(S)$, stream length gradient index $(S L)$, valley floor width to valley height ratio $\left(V_{f}\right)$, mountain front sinuosity index $\left(S_{m f}\right)$, hypsometric integral $(\mathrm{Hi})$, basin asymmetry ratio $(A F)$ and basin elongation ratio $(E b)$ calculated along the linear river offsets with respect to longitudinal River segments of the Rivers Basantar, Tarnah, Ujh, Sahaar and Ravi Rivers reveal that terrain is tectonically active and can be placed in tectonic active class I. The fault has an apparent offset of about $2000 \mathrm{~m}$ with it as it crosses the Basantar, the Tarnah, the Ujh, the Sahaar and the Ravi Rivers. The stream offsets upon field and laboratory investigations are developed due to an active sinistral strike slip fault which is being named as Goran fault. This fault has a surface expression of $100 \mathrm{~km}$ extending from the Basantar in the northwest up to the Beas River in the southwest whereas the remaining segment may exist as a hidden fault all along the Himalaya.
\end{abstract}

\section{Keywords}

Active Tectonics, Goran Fault, Stream Offsets, Himalaya

\section{Introduction}

The Himalayan frontal thrust marks the southern boundary of the deformation 
front of the Himalayan orogenic belt [1]. The thrust faulting in the frontal Himalayan terrain is strongly influenced by the spatial and temporal patterns of active deformation recorded on the margin of the orogenic belts. The accumulated strain on account of the continuous northward migration of the Indian plate finds frequent release in the form of seismic events that display a conspicuous inter-relationship amongst the basal decollement surface, rate of thrusting and plate motion rates [2] [3] [4]. The data emerging from the spectacular surface rupturing earthquakes suggest that the current tectonic activity is primarily occurring in the frontal thrust terrain [5]. Active tectonic morphometric studies within the orogenic belts are of significant importance in the context of evaluating the models of deformation, thrust belt kinematics, as also the seismic hazard faced by the population habiting in close proximity to the active faults. [6] discussed the neotectonic activities that have occurred in the Himalayan terrain. [7] described the structure and shortening of the Kangra and Dehra Dun re-entrants of Sub-Himalaya. [8] has done reassessment of earthquake hazard based on a fault-bend fold model of the Himalayan plate. [9] has described the palaeo-seismicity and seismic hazard assessment in the Himalaya. [10] has identified and described the uplift and convergence along the Himalayan Frontal thrust of India. [11] has identified and described neo-tectonic activity near Nada village and Morni Hills in the Himalayan foothills. [12] described the earthquake recurrence and rupture dynamics of Himalayan Frontal Thrust. [13] discussed the convergence across the northwestern Himalaya. [14] discussed reactivation of Himalayan frontal fault system and its implications. [15] described the shutter ridges and sag ponds along the Jainti Devi Fault near Chandigarh. [16] [17] described the neotectonic and seismo-tectonic characterization of the frontal Himalayan terrain. [18] documented recent fold growth and drainage development in the Janauri and Chandigarh anticlines of the Siwalik foothills. The neotectonic activity in the Markanda and Bata River Basins in Himachal Pradesh has been investigated by [19] and their study suggested upliftment and tilting of the Markanda and Bata River Basins due south. Seismites occurring in the frontal Himalayan terrain near Panchkula in Haryana were identified by [20]. [21] assessed the tectonic character of the terrain in the Frontal Siwalik hills near Trilokpur, northwestern Himalaya using remote sensing and tectonic morphometric approach. A comprehensive evaluation of the tectonic morphometric indices in terrain characterization has been attempted by [22]. Besides [23] [24] [25] [26] [27] have also worked on active tectonic aspects in the frontal Himalayan terrain of the northwestern Himalaya. The present study is aimed at identifying the active tectonic elements in the Kashmir Himalaya, especially in the region between the Basantar and the Ravi Rivers, as the Kashmir Himalaya has been considered to represent a seismic gap due to non-availability of historical earthquakes in this region [28] [29] except Kangra earthquake in 1905 and Uri-Muzzafrabad earthquake in 2005.

\section{Geological Setup}

The Middle Miocene to Middle Pleistocene (23.5 m.a. to 1.6 m.a.) Siwalik group 
of rocks are quite well represented in the foothills of the Jammu and Kashmir Himalaya especially in the vicinity of Ravi River. The frontal Siwalik terrain between the Ravi and the Basantar River comprise the Upper Murree formation, the Lower Siwalik subgroup (Mansar Formation), the Middle Siwalik subgroup (Dewal and Mohargarh formations), and the Upper Siwalik subgroup (Uttarbahni and Dughor formations) as given (Figure 1) by [30] [31] (Table 1).

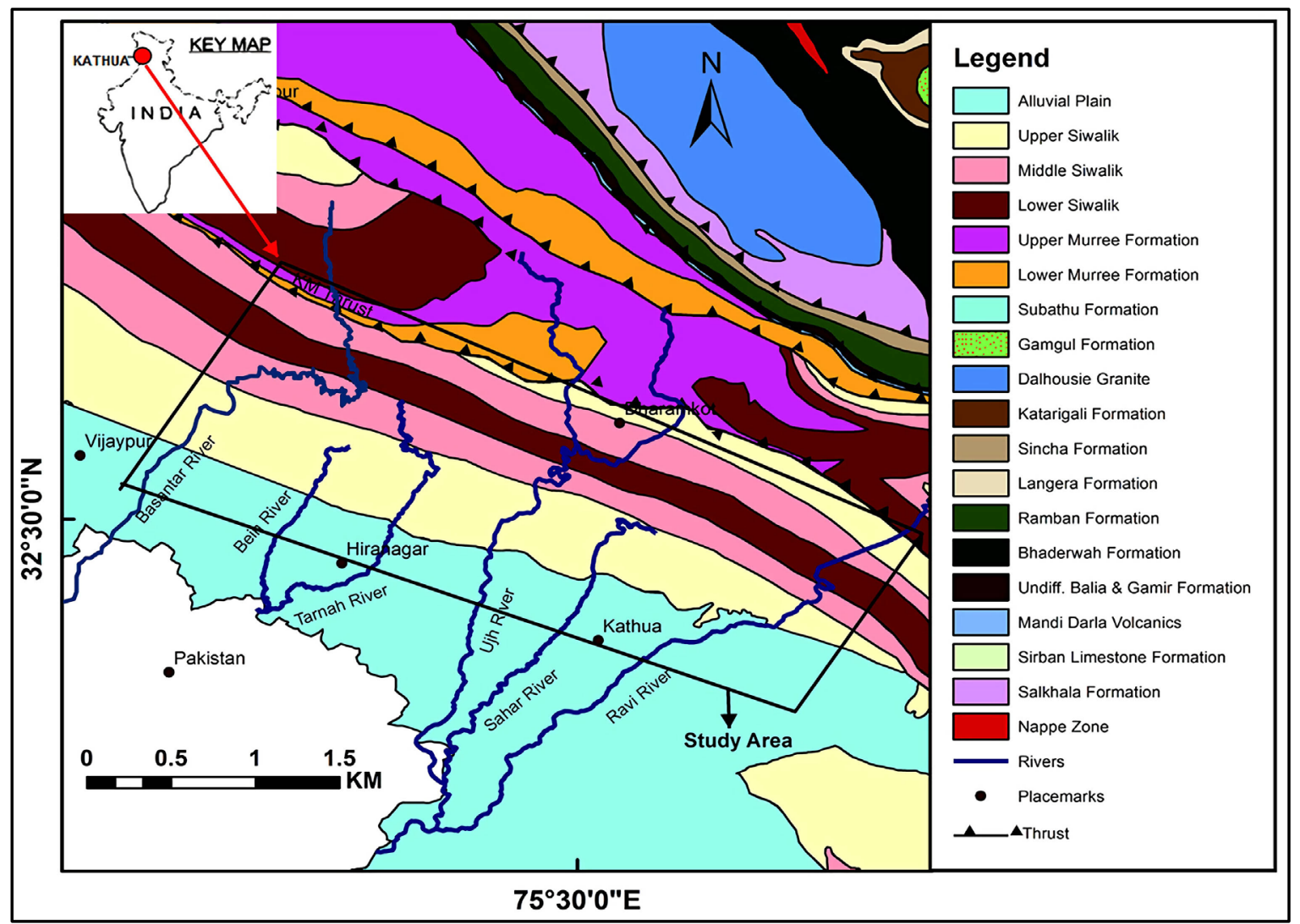

Figure 1. Geological map showing the location of the research area. Modified after GSI map Ref. No. 43P NW Himalaya [32].

Table 1. Lithostratigraphic classification of the area modified after [30] [31] [33].

\begin{tabular}{|c|c|c|c|}
\hline Sub Group & Formation (Equivalent Unit) & Lithology & Age \\
\hline \multirow{6}{*}{ Post-Siwalik } & Terrace (T6) & & \multirow{3}{*}{ Holocene } \\
\hline & Terrace (T5) & 14, 15 and 16 represents fiood prain deposits composing gravel, sand, & \\
\hline & Terrace(T4) (Loess) & & \\
\hline & Terrace $(\mathrm{T} 3)$ & \multirow{3}{*}{$\begin{array}{l}\text { T1, T2 and T3 represents Secondary Boulder Conglomerate deposits } \\
\text { having pale yellow to dark yellow silt matrix as flat-top surfaces. }\end{array}$} & \multirow{3}{*}{ Late Pleistocene } \\
\hline & Terrace (T2) & & \\
\hline & Terrace (T1) (Lei-Conglomerate) & & \\
\hline \multirow{5}{*}{ Upper Siwalik } & Dughor (Boulder Conglomerate) & $\begin{array}{l}\text { Conglomerate to intermittent layers of friable sandstone and rarely } \\
\text { mudstone characterized by orange pigment in the matrix. }\end{array}$ & \multirow[t]{2}{*}{ Middle Pleistocene } \\
\hline & & Sandstones and conglomerates with interbeds of mudstones, laterally & \\
\hline & Nagrota (Pinjor) & grading into conglomerates. & Early Pleistocene \\
\hline & & Mudstones and sandstones alternations with minor conglomerate beds, & \\
\hline & Paramandal (Tatrot) & $\begin{array}{l}\text { laterally changing to grey conglomerate, containing lenticular bands of } \\
\text { sandstone. }\end{array}$ & Late Pliocene \\
\hline
\end{tabular}




\section{Continued}

\begin{tabular}{ccl}
\hline Middle Siwalik & Mohargarh (Dhokpathan) & $\begin{array}{l}\text { Predominantly multistoried sandstones with minor mudstone partings. } \\
\text { Massive, thickly bedded multistoried sandstones with subordinate } \\
\text { mudstones. }\end{array}$ \\
Lower Siwalik & Ramnagar (Chinji) & $\begin{array}{l}\text { Mudstones, siltstones and fine to coarse sandstone alternations. } \\
\text { Very fine to medium sandstones, siltstones and mudstones. }\end{array}$ \\
& Dodenal (Kamlial) & Late Miocene
\end{tabular}

The rocks of the Siwalik group in study area occur as an asymmetrical anticline referred to as the Surin-Masatgarh anticline. The rocks exhibit $N 50^{\circ} \mathrm{W}$ $\mathrm{S} 50^{\circ} \mathrm{E}$ trend with the dominant SW dip direction. The Surin-Masatgarh anticline marks the thrust front [34]. The folding of this anticline has been estimated on the basis of palaeomagnetic data and thermo chronometry. Detritial apatite studies by [35] suggests onset of folding before 2 m.a., while the palaeomagnetic data by [31] [36] suggests an age between 1.6 to 2.1 m.a.

\section{Field Observations}

The southern limb of the asymmetrical Surin-Masatgarh anticline between the Ravi River and the Basantar River is $60 \mathrm{~km}$ in length and $20 \mathrm{~km}$ wide at Basantar re-entrant and 10 to $12 \mathrm{~km}$ wide at Ravi re-entrant. The major geomorphic features identified on the satellite imagery include the Siwalik Hills, alluvial fans, piedmont fan deposits, alluvial plains and River terraces. Low, middle and high hills represent the Upper, Middle and Lower Siwaliks with in between intermontane basins (duns). The Siwalik Hills extend in a NW-SE direction in the form of a linear sinuous asymmetrical anticlinal ridge. The Lower Siwalik Mansar Formation (Lower Miocene to Middle Miocene) comprise well indurated fine to medium grained pale grey to dark grey coloured sandstones, siltstones and mudstones. The Middle Siwalik Dewal Formation (Early Pliocene) and Mohargarh Formation (Middle Pliocene) comprise massive, medium to poorly indurated, pale grey to light brown coloured sandstones, siltstones and mudstone. The upper Siwalik Parmandal formation (Late Pliocene) comprises light brown to dark grey sandstone and mudstone with minor intercalations of pebbly beds that grades into sandstone and conglomerate in Nagrota $\mathrm{fm}$. The Nagrota formation (Early Pleistocene) is represented by light to dark grey to pale brown sandstone and mudstone in the lower part and coarser clastics in the upper part. The upper Siwalik Dughor formation (Middle Pleistocene) represent the Boulder Conglomerate unit and is represented by matrix supported polymictic friable conglomerate containing sandstone lenses and thin beds of friable sandstone and mudstone. Alluvial fans comprise a chaotic intermix of cobbles, pebbles, granules, sand, silt and clay particles which at places are intermixed with calcareous concretions. The piedmont plains are made up of poorly sorted debris, assorted sediments debouched by streams, draining the region. The terrain between the Ravi River and the Basantar River is being closely examined to identify active tectonic features in the terrain. Development of shutter ridges is observed along 
all the streams through which the linear tectonic element crosses on the basis of movement seen along this element, which is being named as Goran fault. The fault is active and trends northwest-southeastwards. This fault is a sinistral strike slip fault with considerable oblique slip component. The fault has a surface expression of about $100 \mathrm{~km}$ and a significant portion of it appears to be hidden.

Fault scarps are observed in the Ujh River near Jakhole village in the Kathua district of Jammu and Kashmir (Figure 2(a)). Triangular facets along the Goran fault are observed along the Ravi River near Basantpur-Jugial region (Figure 2(b)). Shutter ridges of $2000 \mathrm{~m}$ length are developed along all Rivers and major streams (Figure 2(c)). Development of sag pond is observed along the Ujh River (Figure 2(d)). Unpaired terraces have been identified in the vicinity of Ravi River near Basantpur-Jugial region (Figure 3). During field work in the Jugial

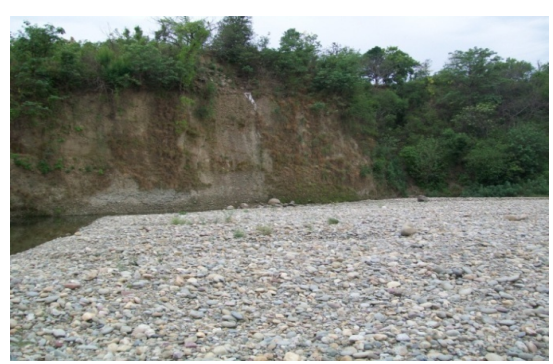

(a)

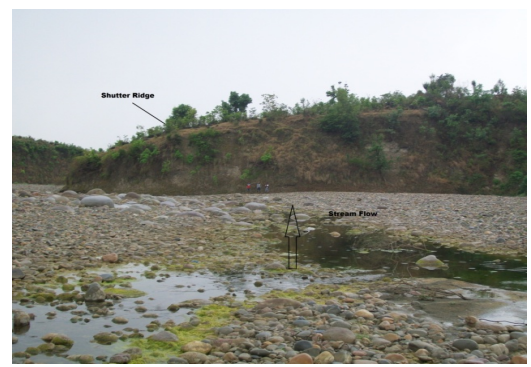

(c)

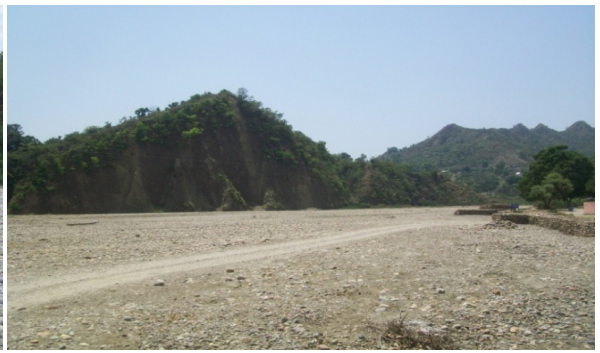

(b)

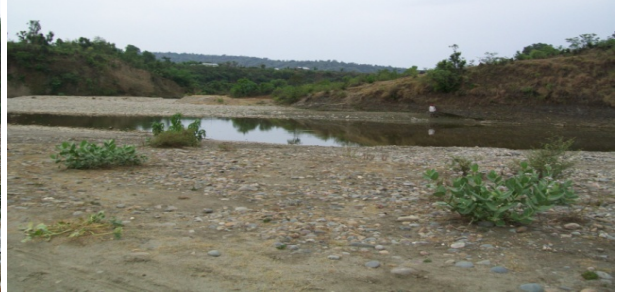

(d)

Figure 2. Field photographs of the structures observed in the Frontal Himalayan terrain, Kathua District, Jammu \& Kashmir ((a) Fault Scarp; (b) Triangular Facets; (c) Shutter Ridge; (d) Sag Pond).

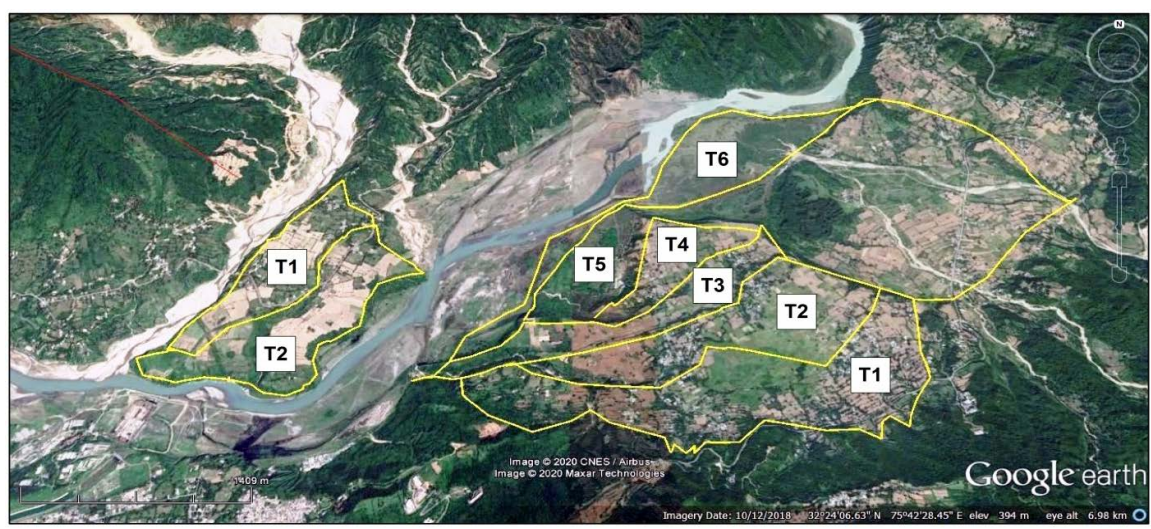

Figure 3. Google earth image showing unpaired terraces along the Ravi River. 
region six terraces (T1, T2, T3, T4, T5 \& T6) have been identified on the left bank of the Ravi River while only strath terraces (T1 \& T2) have been identified on the right bank of the Ravi River. The terraces are made up of unconsolidated pebbles, sand, silt and clay. The younger terraces namely T5 and T6 are more fragile as compared to the older terraces.

\section{Methodology}

The active tectonic characterization of the terrain in the vicinity of Ravi River in the frontal Siwalik terrain is carried out in a multidisciplinary manner. The data obtained from comprehensive field surveys, satellite imageries and morphometric investigations is being analyzed to ascertain the tectonics of the area of investigation. The Google Earth images (Figure 4) and LISS-III imageries (Figure 5) are being analyzed for visual identification and interpretation of geologic and geomorphic features.

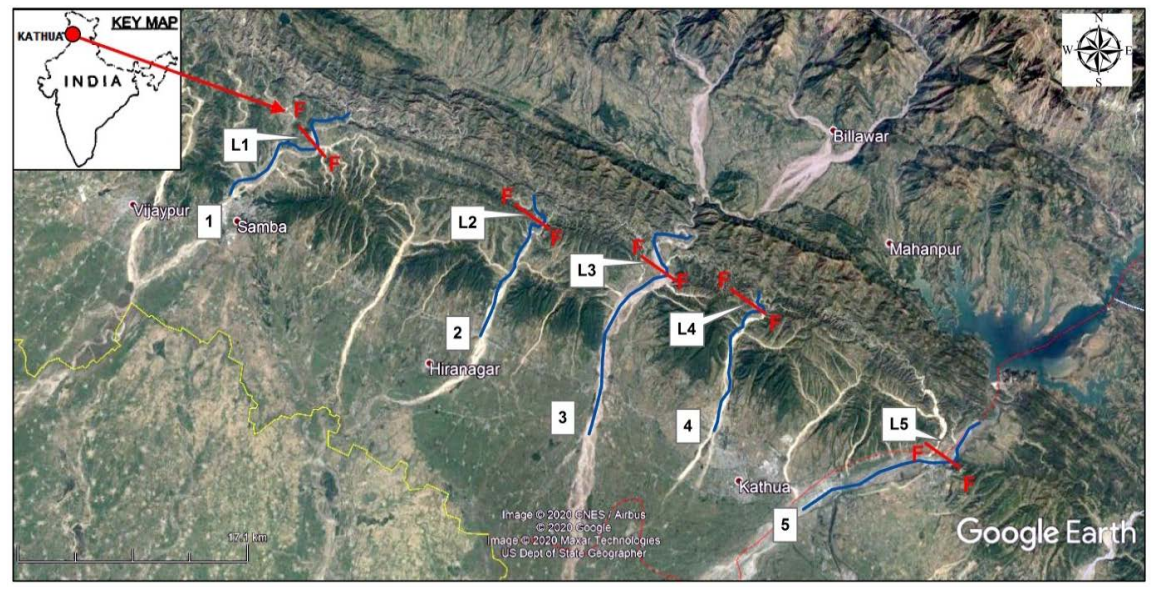

Figure 4. True Colour Google Earth Images showing the location along which River offsets (L1 to L5) and longitudinal profile segments (1 to 5) of different streams have been studied for computing morphometric parameters.

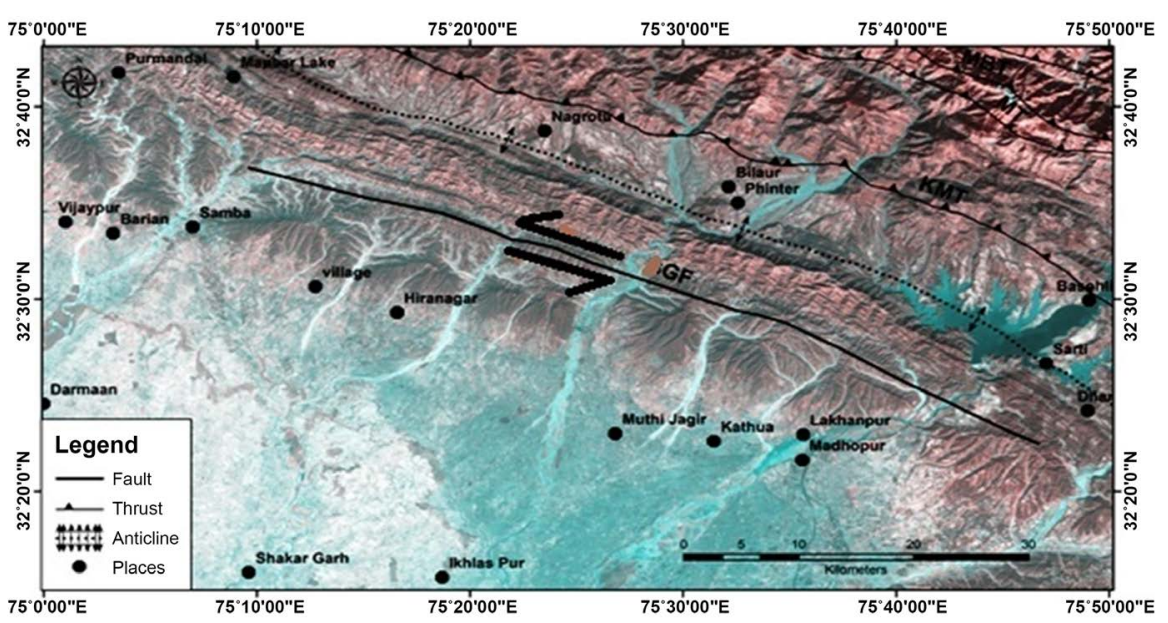

Figure 5. LISS III false colour composite image (Resourcesat: 1, 2010) [41] showing the location of the fault. GF-Goran Fault. 
Active tectonic geomorphic indices viz. stream length gradient index by [37], stream sinuosity index [38], mountain front sinuosity index, ratio of valley floor to valley height [39] [40] hypsometric integral, asymmetry factor and basin elongation ratio have been computed for the affected portion of the terrain in the region. The features identified and interpreted on the imageries and the data generated through ArcGIS have been physically verified in the field through comprehensive field investigations. The Digital Elevation Model (DEM) of the selected terrain has been prepared and the LISS-III false colour composite imagery has been draped over it to understand the tectonic character of the region.

\section{Morphometric Analysis}

Morphotectonic analysis is widely used as a basic reconnaissance tool for geomorphic evaluation of active tectonics. The morphotectonic indices computed to substantiate the role of active tectonics in research area have been briefly discussed below. The channel morphology, the fluvial processes and the hydrological characteristics of a River are significantly influenced by the tectonic deformation processes. During the course of study significant water channels, namely the Ravi, the Ujh the Basantar with their tributaries namely the Sahaar stream and the Tarnah stream have been examined in detail to identify the signatures of presence of active tectonic control in the area of the investigation.

Morphometric analysis of the streams was carried out on the basis of lineament analysis and anomalous stream offsets. The vector layer for lineament was digitized. The linear element has resulted in stream offsets along all the streams that cross its surface trace. The stream offset (L1) for the Basantar River is 2000 $\mathrm{m}$, stream offset (L2) for the Tarnah stream is $2000 \mathrm{~m}$, stream offset (L3) for the Ujh River is $2000 \mathrm{~m}$, stream offset (L4) for the Sahaar stream is $2000 \mathrm{~m}$ and stream offset (L5) for the Ravi River is $2000 \mathrm{~m}$ (Figure 4). The tectonic morphometric analysis for stream offsets L1 to L5 is being carried out and the tectonomorphometric indices namely stream length gradient index $(S L)$, stream sinuosity index $(S)$, mountain front sinuosity index $\left(S_{m f}\right)$, basin asymmetry ratio $(A F)$, basin elongation ratio $(E b)$, valley floor width to valley height ratio $\left(V_{f}\right)$ and hypsometric integral (Hi) for all the River segments viz. Basantar (1), Tarnah (2), Ujh (3), Sahaar (4) and Ravi (5) have been computed.

\subsection{Stream Sinuosity Index $(S)$}

The Stream Sinuosity index helps in understanding the affect of tectonic character of the terrain on the River course. It is defined as the ratio of the channel length $(C$ ) to the valley length ( $V$ ) i.e. $S=C / V$ by [38] [42]. The $S$ value more than 1.5 indicates the sinuous course. The $S$ values for the Basantar River, the Tarnah stream, the Ujh River and the Sahaar stream and the Ravi River are 1.54, $1.714,1.928$ and $1.545 \& 1.868$ respectively. High $S$ values indicate that the terrain is tectonically active. 


\subsection{Stream Length Gradient Index (SL)}

The Stream Length Gradient Index $(S L)$ is the rate of change of slope and provides a quantitative measure of tectonic activity or quiescence in a basin [43]. Mathematically, it is defined as, $S L=\Delta H \cdot L / \Delta L$, where $\Delta H$ is the change in elevation of the stream flow in the active segment and $\Delta L$ is the length of the active segment and $L$ is the length of stream from its origin to the active segment. High $S L$ values are indicative of high rates of tectonic uplift. $S L$ values for the Basantar River, the Tarnah stream, the Ujh River, the Sahaar stream and the Ravi River (Figure 6) are 345, 144, 510, 221 and 183 respectively which are high and indicate tectonically active nature of the terrain.

\subsection{Valley Floor Width to Valley Height Ratio $\left(V_{f}\right)$}

The Valley Floor Width to Valley Height Ratio $\left(V_{f}\right)$ was defined by [44] and later by [45] as $V_{f}=2 V_{f w} /\left[\left(E_{l d}-E_{s d} / E_{r d}-E_{s c}\right)\right]$, where $V_{f w}$ is the width of the valley
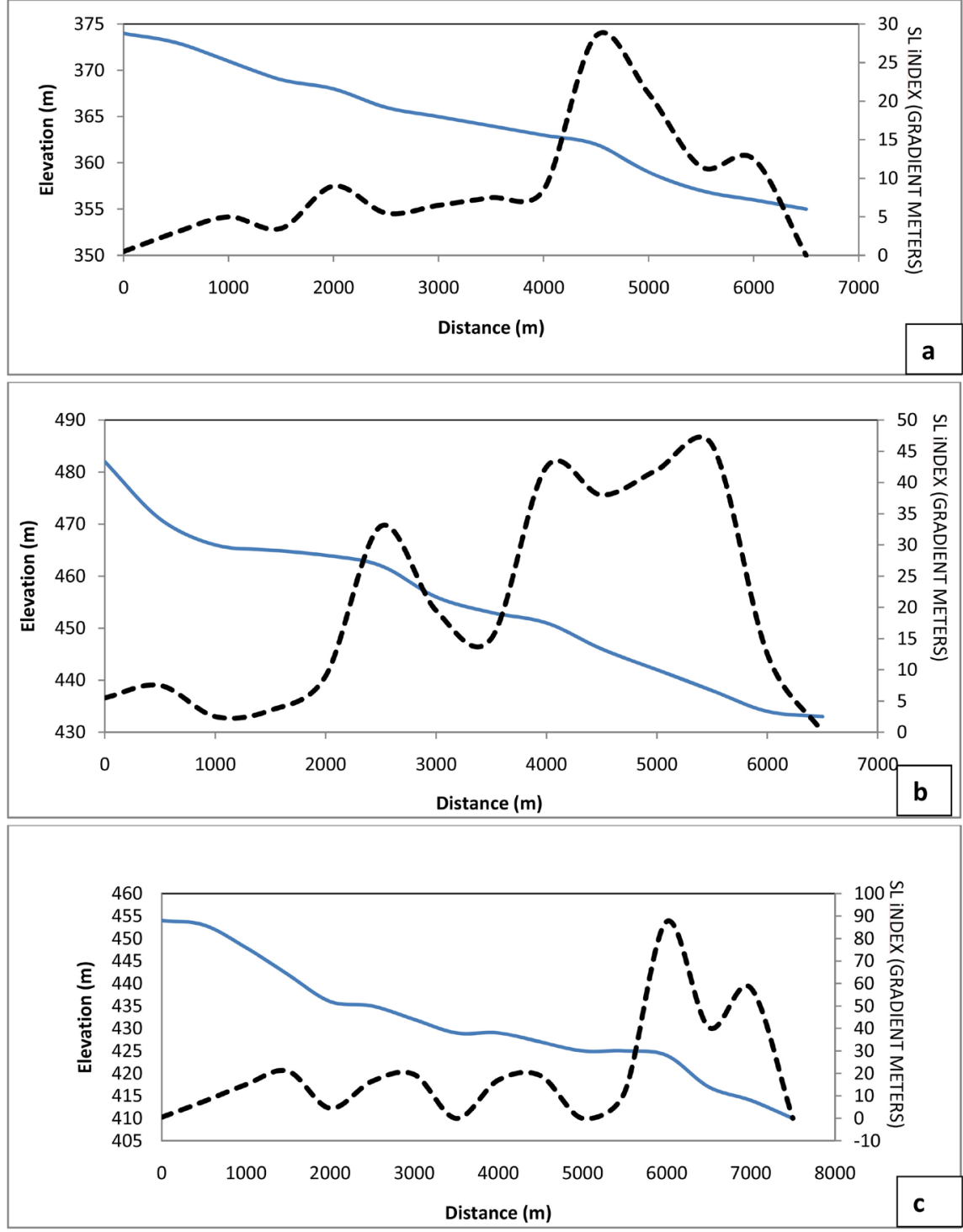

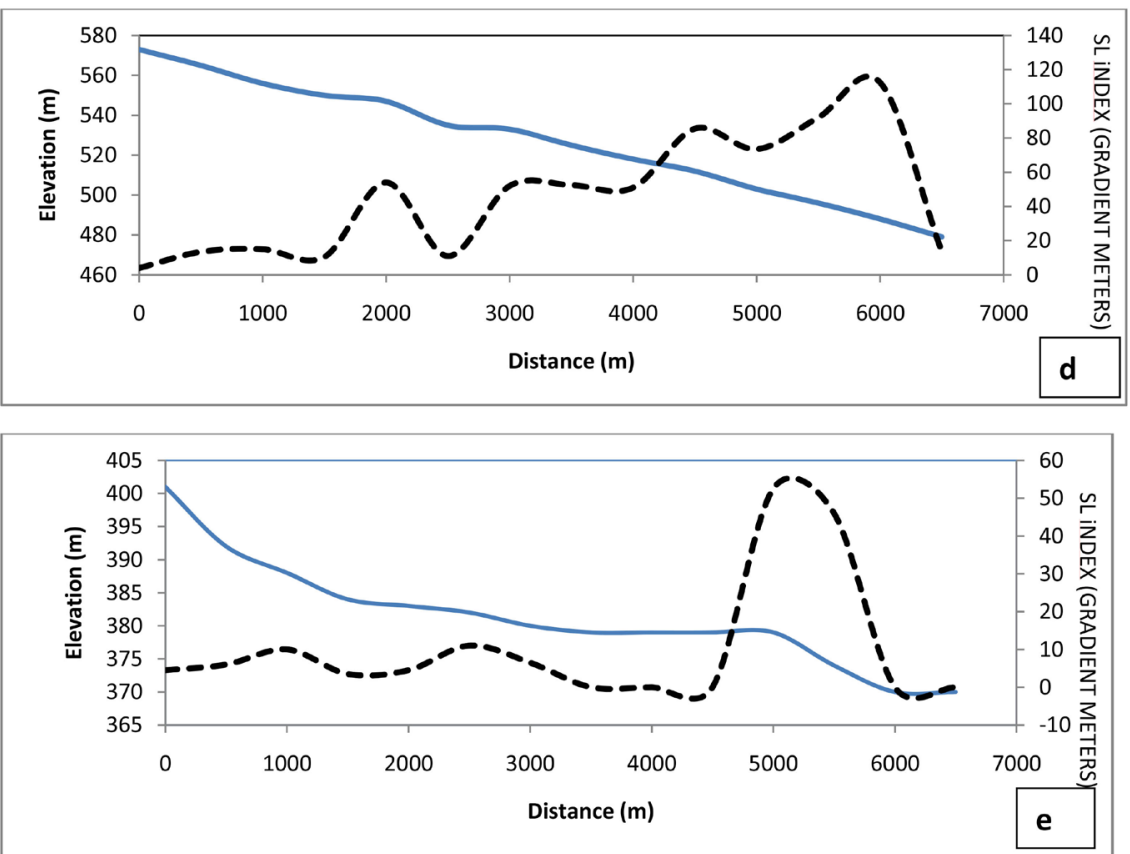

Figure 6. Longitudinal profile ( - ) and Stream Length gradient index (--------) of River segments ((a) Basantar River, (b) Tarnah stream, (c) Ujh River, (d) Sahaar stream and (e) Ravi River). The peak SL index values are sensitive to the sudden change in elevation of the longitudinal profile which indicates the trace of active fault.

floor, $E_{l d}$ is the maximum elevation to the left side of the defected segment, $E_{r d}$ is the maximum elevation to the right side and $E_{s c}$ is the elevation of valley floor at the deflected segment. This is a useful index that measures effectiveness of stream down cutting in response to the tectonic uplift [44]. When calculating $V_{f}$ these parameters are measured at a set distance from the mountain front for every valley studied. It helps to discriminate between broad, flat floored canyons (with high values of $V_{f}$ as $>1$ ) with major lateral erosion in response to base level stability or tectonic quiescence, from the $V$-shaped valleys (with relatively low values of $V_{f}$ as $<1$ ) formed as a result of active down cutting in response to tectonic uplift. High values are reflective of low tectonic activity whereas low values are associated with tectonically active areas undergoing rapid uplift and valleys incision [45]. The $V_{f}$ for the Basantar River is 0.359; for the Tarnah stream is 0.750; for the Ujh River is 0.941; for the Sahaar stream is 0.739 and for the Ravi River 0.121 . Low $V_{f}$ values varying from 0.121 to 0.941 indicate that the terrain is tectonically active.

\subsection{Mountain Front Sinuosity Index $\left(S_{m f}\right)$}

Mountain Front Sinuosity Index is a reconnaissance tool to identify areas of tectonic activity. It is defined as the ratio of length of the mountain front $\left(L_{m f}\right)$ along foot of the mountain at the pronounced break of slope to the straight line length $\left(L_{s}\right)$ of the mountain front. i.e. $S_{m f}=L_{m f} L_{s}$. The $S_{m f}$ reflects the balance between erosion producing irregular/sinuous fronts and tectonic forces creating 
straight mountain fronts. Tectonically active mountain fronts have $S_{m f}$ less than 1.4as given by [46]. Mountain front with lesser activity, but still reflecting active tectonics have $S_{m f}$ value between 1.4 and 3, whereas $S_{m f}$ values more than 3 reflects inactive mountain fronts [45]. The $S_{m f}$ value for the hill ranges along the Basantar River is 1.58; along the Tarnah stream is 1.453; along the Ujh River is 1.216; along the Sahaar stream is 1.550 and hills bordering along the Ravi River is 1.6. The $S_{m f}$ values along all localities are less than 1.6 that indicates the terrain is tectonically active.

\subsection{Drainage Basin Asymmetry Factor $(A F)$}

Drainage basin asymmetry analysis helps in finding out the neotectonic activity in an area. Drainage basin asymmetry has been used as a tool to identify quaternary tilting [47]. The Asymmetry Factor is a qualitative index that helps in evaluating basin asymmetry. It is defined as the $A F=A r / A t$, where $A r$ is the total area along the right side of the stream and At is the total area of the basin. In a stable environment $A F$ is 50, whereas the value more or less suggests the tilt in the basin that represents neotectonic activity [43]. The values of $A F$ for Basantar, Tarnah, Sahaar and Ravi Rivers are 34.3, 45.56, 44, and 22.34 respectively indicating the tilt towards right, whereas $A F$ for Ujh River is 65.54 reflecting terrain tilting in left direction.

\subsection{Hypsometric Integral (Hi)}

The Hypsometric integral is defined as the distribution of different elevations across a landscape that can be evaluated over a small area to a large area extending from a single drainage basin to the entire surface of the earth. Mathematically it is defined as [(mean elevation-minimum elevation)/(maximum elevation-minimum elevation)]. Hypsometric analysis is a powerful tool for differentiating tectonically active from inactive regions. High Hi values are associated with higher rates of tectonic activity and linear range fronts [44] [48]. Hypsometric integral value for the Basantar River is 0.421 , for the Tarnah stream is 0.395 , for the Ujh River is 0.415 , for the Sahaar stream is 0.400 and for the Ravi River is 0.421 indicating that the terrain is tectonically active.

\subsection{Basin Elongation Ratio $(E b)$}

The Basin elongation ratio is one of the proxy indicators of neotectonic activity [44]. [49] defined the basin elongation ratio as the ratio of diameter of a circle having the same area $(A)$ as the basin to the maximum length $(L)$ of the basin. Mathematically, it is defined as $E b=[(2 A / \pi) / 1 / 2] / L$. The $E b$ values below 0.50, in between 0.50 and 0.750 and more than 0.750 are characteristics of tectonically active, slightly active and inactive terrain settings respectively. The $E b$ value for the Basantar River is 0.460 , for the Tarnah stream is 0.478 , for the Ujh River is 0.354 , for the Sahaar stream is 0.579 and for the Ravi River is 0.380 . According to [50] the basin with $E b<0.600$ is tectonically active. The $E b$ value for each region 
is low varying from 0.354 to 0.579 indicating tectonically active nature of the terrain.

\subsection{Knick Points}

All channels viz. the Basantar River, the Tarnah stream, the Ujh River, the Sahaar stream and the Ravi River have knick points along the River segments where the fault is crossing these channels (Figure 7). Along the knick points in the longitudinal River segment there is sudden change in the profile of the Rivers. This break in slope in a graded profile represents the trace of the active tectonic activity.
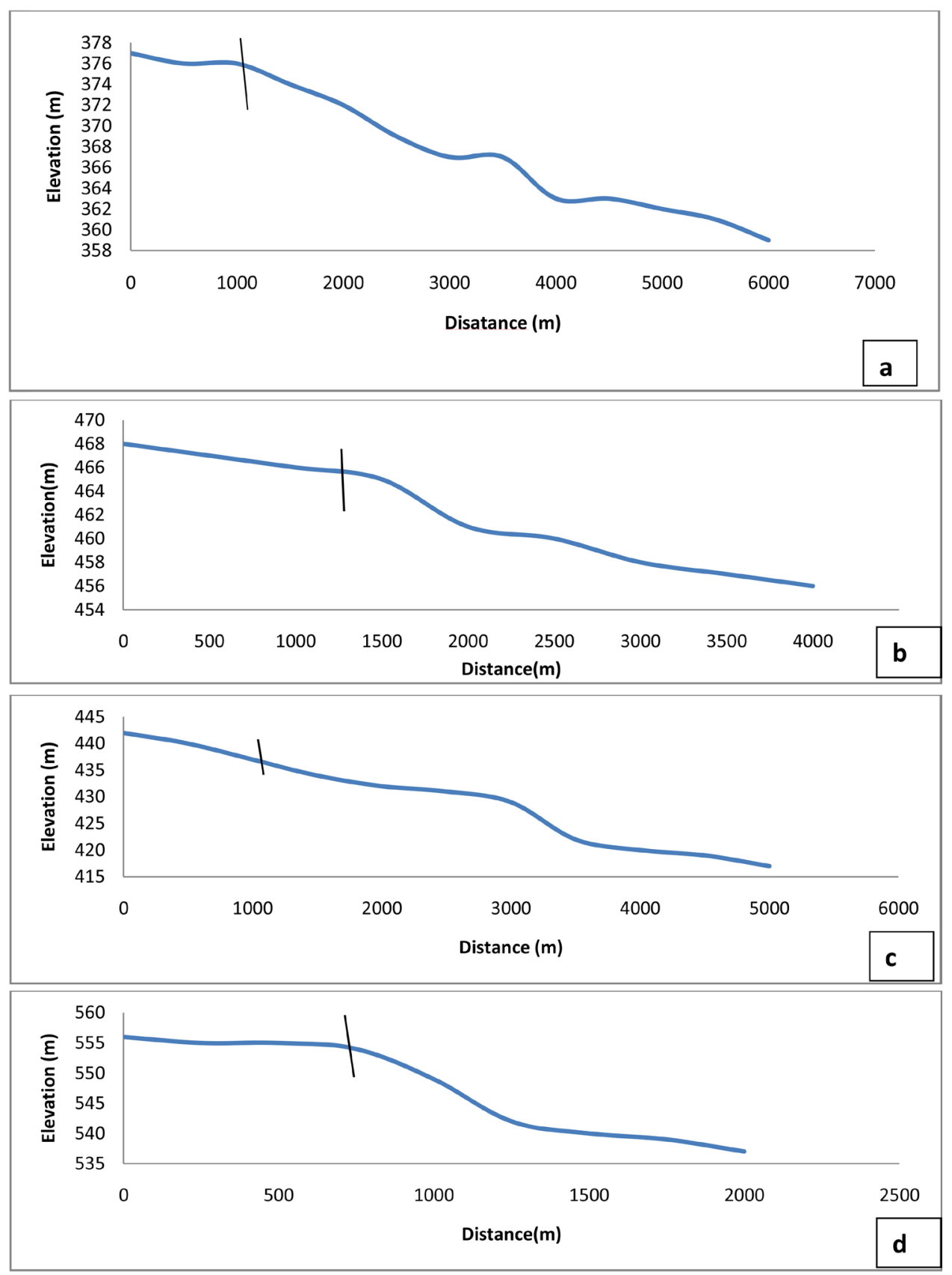


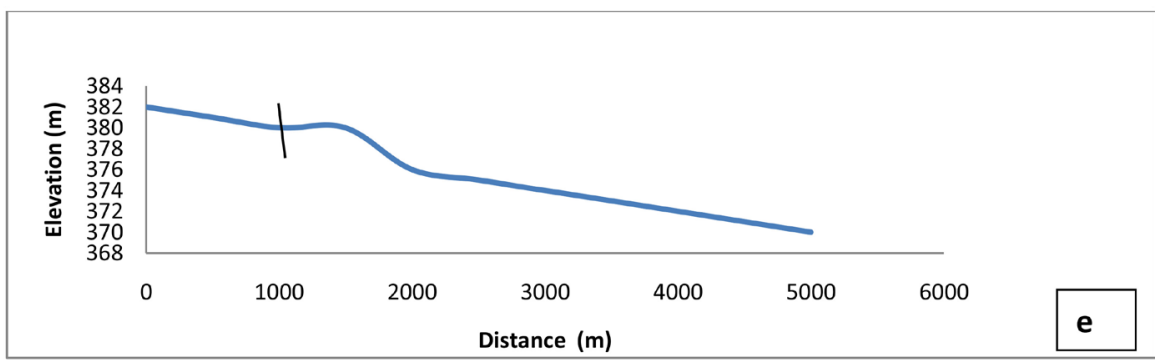

Figure 7. Longitudinal profile of River segments showing knick points where the trace of active fault crosses the channels ((a) Basantar River, (b) Tarnah stream, (c) Ujh River, (d) Sahaar stream and (e) Ravi River)

\section{Discussion}

The Samba and the Kathua ditricts of Jammu and Kashmir are densely populated. Majority of the rural folk live in the non-masonary structures. Majority of such structures are built on the hill slopes and are vulnerable to seismic shaking. The Kangra earthquake (1905) and the Uri-Muzzfrabad earthquake (2005) caused considerable damage to life and property in this region. Identification of active faults is a significant parameter in assessing the seismotectonics of a region. It is in this context that the region between the Basantar and the Ravi Rivers is being closely examined to identify active faults on the basis of tectonic morphometric indices and field studies. The values of the various indices viz. stream sinuosity $(S)$, stream length gradient index $(S L)$, valley floor width to valley height ratio $\left(V_{f}\right)$, mountain front sinuosity index $\left(S_{m f}\right)$, hypsometry index $(\mathrm{Hi})$, drainage basin asymmetry factor $(A F)$ and basin elongation ratio $(E b)$ reveal active tectonic character of the terrain.

\section{Conclusion}

The terrain between the Basantar River and the Ravi River has been closely examined. The tectonic morphometric indices along the Ravi River, the Sahaar stream, the Ujh River, the Tarnah stream and the Basantar River are indicative of active tectonic setup of the terrain. The field observations in conjunction with remote sensing investigations of the study area reveal the presence of an active sinistral strike slip fault which is named as Goran Fault. This fault has a surface expression of around $100 \mathrm{~km}$ and it is a significant seismo-tectonic element which needs to be taken into account considering the seismically active nature of the frontal Himalayan terrain of the Kashmir Himalaya. Future studies should consider a comprehensive subsurface investigation by appropriate geophysical techniques to identify and characterize the tectonic setup of the populated Himalayan foothills.

\section{Acknowledgements}

The research work was carried out in Department of Geology, Kurukshetra University, Kurukshetra. The authors are thankful to scholars of the sedimen- 
tology group namely Dr. Rajesh Ranga, Messers Yoginder Singh and Subhash for their assistance in field and laboratory investigations.

\section{Conflicts of Interest}

The authors declare no conflicts of interest regarding the publication of this paper.

\section{References}

[1] Di Pietro, J.A. and Pogue, K.R. (2004) Tectonostratigraphic Subdivisions of the Himalaya: A View from the West. Tectonics, 23, TC5001. https://doi.org/10.1029/2003TC001554

[2] Bilham, R., Gaur, V.K. and Molnar, P. (2001) Himalayan Seismic Hazard. Science, 293, 1442-1444. https://doi.org/10.1126/science.1062584

[3] Lavé, J. and Avouac, P. (2000) Active Folding of Fluvial Terraces across the Siwaliks Hills: Himalayas of Central Nepal. Journal of Geophysical Research, 105, 5735-5770. https://doi.org/10.1029/1999JB900292

[4] Mugnier, J.L., Huyghe, P., Leturmy, P. and Jouanne, F. (2004) Episodicity and Rates of Thrust-Sheet Motion in the Himalayas (Western Nepal). In: McClay, K.R., Ed., Thrust Tectonics and Hydrocarbon Systems, Volume 82, AAPG Memoirs, New York, 91-114.

[5] Nakata, T. (1989) Active Fauls of the Himalaya of India and Nepal. In: Malinconinco Jr., L.L. and Lillie, R.J., Eds., Tectonics of the Western Himalayas, Geological Society of America, Boulder, CO, 243-264 . https://doi.org/10.1130/SPE232-p243

[6] Valdiya, K.S. (1986) Neotectonic Activities in the Himalayan Belt. In: Proceedings of International Symposium on Neotectonics in South Asia, Survey of India, Dehra Dun, $434 \mathrm{p}$.

[7] Powers, P.M., Lillie, R.J. and Yeats, R.S. (1998) Structure and Shortening of the Kangra and Dehra Dun Reentrants, Sub-Himalaya, India. Geological Society of America Bulletin, 110, 1010-1027. https://doi.org/10.1130/0016-7606(1998)110<1010:SASOTK>2.3.CO;2

[8] Yeats, R.S. and Thakur, V.C. (1998) Reassessment of Earthquake Hazard Based on a Fault-Bend Fold Model of the Himalayan Plate-Boundary Fault. Current Science, 74, 230-233.

[9] Thakur, V.C., Yeats, R.S. and Virdi, N.S. (1999) Paleoseismicity and Seismic Hazard Assessment in the Himalaya. Proceedings of Indo-US Workshop on Paleoseismicity with Reference to Seismic Hazard Assessment in the Himalaya. Himalayan Geology, $20,152$.

[10] Wesnousky, G.W., Kumar, S., Mohindra, R. and Thakur, V.C. (1999) Uplift and Convergence along the Himalayan Frontal Thrust of India. Tectonics, 18, 967-976. https://doi.org/10.1029/1999TC900026

[11] Gupta, L.N., Kumar, R. and Gill, G.S. (2001) Neotectonic in the Himalaya Foothills: Surface Manifestations near Nada Village and Morni Hills. Bulletin of The Indian Geologists Association, 34, 257-272.

[12] Kumar, S., Wesnousky, S.G., Rockwell, T.K., Ragona, D., Thakur, V.C. and Seitz, G.G. (2001) Earthquake Recurrence and Rupture Dynamics of Himalayan Frontal Thrust, India. Science, 294, 2328-2331. https://doi.org/10.1126/science.1066195 
[13] Banerjee, P. and Burgman, R. (2002) Convergence across the Northwest Himalaya from GPS Measurements. Geophysical Research Letters, 29, 301-304. https://doi.org/10.1029/2002GL015184

[14] Valdiya, K.S. (2003) Reactivation of Himalayan Frontal Fault: Implications. Current Science, 85, 1031-1040.

[15] Chaudhri, A.R. (2005) Shutter Ridges and Sag Ponds along the Chandigarh Fault, Northwestern Himalaya. Seismology Update, 1, 6.

[16] Chaudhri, A.R. (2007) Neotectonic Activities in the Himalayan Foothill Region: A Case Study. In: Varma, O.P., Mahajan, A.K. and Gupta, V., Eds., Natural Hazards, Indian Geological Congress, Roorkee, 73-83.

[17] Chaudhri, A.R. (2007) Seismo-Tectonic Characterization of the Himalayan Foothill Region: A Case Study. In: Saklani, P.S., Ed., Himalaya (Geological Aspects), Volume 5, Satish Serial Publishing House, New Delhi, 41-50.

[18] Delcaillau, B., Carroza, J.M. and Laville, E. (2006) Recent Fold Growth and Drainage Development: The Janauri and Chandigarh Anticlines in the Siwalik Foothills, Northwest India. Geomorphology, 76, 241-256.

https://doi.org/10.1016/j.geomorph.2005.11.005

[19] Virdi, N.S. and Bhattacharya, S. (2006) Neotectonic Activity in the Markanda and Bata River Basins, Himachal Pradesh, NW Himalaya: A Morphotectonic Approach. International Journal of Remote Sensing, 27, 2093-2099. https://doi.org/10.1080/01431160500445316

[20] Chaudhri, A.R. (2009) Soft Sediment Deformational Features (Seismites) as a Potential Tool for Seismic Hazard Assessment: A Case Study. The Journal of Indian Association, 28, 49-53.

[21] Chaudhri, A.R. (2011) Assessing Tectonic Character of the Terrain in the Frontal Siwalik Hills near Trilokpur, Northwestern Himalaya Using Remote Sensing and Tectonic Morphometric Approach. International Journal of Earth Sciences and Engineering, 4, 787-795.

[22] Chaudhri, A.R. (2012) Tectonic Morphometric Studies as a Tool for Terrain Characterization in the Himalayan Foothill Region: A Case Study. Journal Geological Society of India, 79, 210-218. https://doi.org/10.1007/s12594-012-0025-z

[23] Malik, J.N. and Nakata, T., (2003) Active Faults and Related Late Quaternary Deformation along the Northwestern Himalayan Frontal Zone. Indian Annals of Geophysics, 46, 917-936.

[24] Malik, J.N. and Mohanty, C. (2007) Active Tectonic Influence on the Evolution of Drainage and Landscape: Geomorphic Signatures from Frontal and Hinterland Areas along Northwestern Himalaya, India. Journal of Asian Earth Sciences, 29, 604-618. https://doi.org/10.1016/j.jseaes.2006.03.010

[25] Malik, J.N., Shah, A.A., Sahoo, A.K., Puhan, B., Banerjee, C., Shinde, D.P., Juyal, N., Singhvi, A.K. and Rath, S.K. (2010) Active Fault, Fault Growth and Segment Linkage along the Janauri Anticline (Frontal Foreland Fold), NW Himalaya, India. Tectonophysics, 483, 327-343. https://doi.org/10.1016/j.tecto.2009.10.028

[26] Malik, J.N., Sahoo, A.K., Shah, A.A., Shinde, D.P., Juyal, N. and Singhvi, A.K. (2010) Paleoseismic Evidence from Trench Investigation along Hajipur Fault, Himalayan Frontal Thrust, NW Himalaya: Implication of the Faulting Pattern on Landscape Evolution and Seismic Hazard. Journal of Structural Geology, 32, 350-361. https://doi.org/10.1016/j.jsg.2010.01.005

[27] Malik, J.N., Sahoo, S., Satuluri, S. and Okumura, K. (2015) Active Fault and Paleoseismic Studies in Kangra Valley: Evidence of Surface Rupture of a Great Hima- 
layan 1905 Kangra Earthquake (Mw 7.8), Northwest Himalaya, India. Bulletin of the Seismological Society of America, 105, 2325-2342. https://doi.org/10.1785/0120140304

[28] Khattri, K. (1999) Probabilities of Occurrence of Great Earthquakes in the Himalaya. Proceedings of the Indian Academy of Sciences. Earth and Planetary Sciences, 108, 87-92.

[29] Scheiffman, C., Bali, B.S., Szeliga, W. and Bilham, R. (2013) Seismic Slip Deficit in the Kashmir Himalaya from GPS Observations. Geophysical Research Letters, 40, 5642-5645. https://doi.org/10.1002/2013GL057700

[30] Ranga Rao, A., Agarwal, R.P., Sharma, U.N., Bhalla, M.S. and Nanda, A.C. (1988) Magnetic Polarity Stratigraphy and Vertebrate Paleontology of the Upper Siwalik Subgroup of Jammu Hills, India. Journal of the Geological Society of India, 31, 361-385.

[31] Gupta, S.S. and Verma, B.C. (1988) Stratigraphy and Vertebrate Fauna of the Siwalik Jammu District Group, Mansar-Uttarbani Section, J\&K. Journal of the Palaeontological Society of India, 33, 117-124.

[32] GSI (1995) Geological Quadrangle Map of Himachal Pradesh, Jammu and Kashmir and Punjab. Geological Society of India. Scale 1:2,50000.

[33] Pandita, S.K. and Bhat, S.K. (2011) Depositional and Diagenetic History of the Lower Siwalik Subgroup (Miocene), Northwest Himalaya. Poster Presentation at AAPG International Convention and Exhibition, Milan, Italy.

[34] Rango Rao, A. and Dutta, N.K. (1976) Geological Map of the Himalayan Foot-Hills. Oil and Natural Gas Commission, Sheet A.

[35] Gavillot, Y. (2014) Late Cenozoic-Recent Exhumation History of the Kashmir Himalaya from the Siwalik Murree Belt to the High Himalaya Using (U-Th/He) Thermochronometry. Ph.D. Thesis, the Oregon State University, Corvallis, OR, 214.

[36] Burbank, D.W., Raynolds, R.G.H. and Johnson, G.D. (1986) Late Cenozoic Tectonics and Sedimentation in the North-Western Himalayan Foredeep: II. Eastern Limb of the Northwest Syntaxis and Regional Synthesis. International Association of Sedimentologists, 8, 293-306. https://doi.org/10.1002/9781444303810.ch16

[37] Hack, J.T. (1973) Stream Profile Analysis and Stream Gradient Index. Journal of Research of the U.S. Geological Survey, 1, 421-429.

[38] Gomez, B. and Marron, D.C. (1991) Neotectonic Effects on Sinuosity and Channel Migration, Belle Fourche River, Western South Dakota. Earth Surface Processes and Landforms, 16, 227-235. https://doi.org/10.1002/esp.3290160304

[39] Bull, W.B. (1977) Tectonic Geomorphology of the Mojave Desert. USGS Contract Report, Office of Earthquakes, Volcanoes and Engineering, Menlo Park, CA.

[40] Bull, W.B. (1978) Geomorphic Tectonic Classes of the South front of the San Gabriel mountains, California. USGS Contract Report, Office of Earthquakes, Volcanoes and Engineering, Menlo Park, CA.

[41] Resourcesat: 1 (2010) LISS-III Satellite Imageries, 30 Meter Resolution. National Remote Sensing Center, Hyderabad.

[42] Muller, J.E. (1968) An Introduction to the Hydraulic and Topographic Sinuosity Indexes. Annals Association of American Geographers, 58, 371-385. https://doi.org/10.1111/j.1467-8306.1968.tb00650.x

[43] Keller, E.A. and Pinter, N. (1996) Active Tectonics: Earthquakes, Uplift and Landscape. Prentice Hall Publishers, Upper Saddle River, NJ, 338.

[44] Bull, W.B. and McFadden, L.D. (1977) Tectonic Geomorphology North and South 
of the Garlock Fault, California. In: Doehring, D.O., Ed., Geomorphology of Arid Regions. Proceedings of the Eighth Annual Geomorphology Symposium, State University of New York at Binghamton, Binghamton, 115-138.

[45] Keller, E.A. and Pinter, N. (2002) Active Tectonics, Earthquakes, Uplift and Landscape. 2nd Edition, Prentice Hall, Upper Saddle River, NJ, 362.

[46] Rockwell, T.K., Keller, E.A., Clark, M.N. and Johnson, D.L. (1984) Chronology and Rates of Faulting of Ventura River Terraces. California Geological Society of America Bulletin, 95, 1466-1474.

https://doi.org/10.1130/0016-7606(1984)95<1466:CAROFO>2.0.CO;2

[47] Cox, R.T. (1994) Analysis of Drainage-Basin Symmetry as a Rapid Technique to Identify Areas of Possible Quaternary Tilt-Block Tectonics: An Example from the Mississippi Embayment. Geological Society of America Bulletin, 106, 571-581. https://doi.org/10.1130/0016-7606(1994)106<0571:AODBSA >2.3.CO;2

[48] Strahler, A.N. (1952) Hypsometric Analysis of Erosional Topography. Bulletin of the Geological Society of America, 63, 1117-1142. https://doi.org/10.1130/0016-7606(1952)63[1117:HAAOET]2.0.CO;2

[49] Schumm, S.A. (1956) Evolution of Drainage Systems \& Slopes in Badlands at Perth Anboy, New Jersey. Bulletin of the Geological Society of America, 67, 597-646. https://doi.org/10.1130/0016-7606(1956)67[597:EODSAS]2.0.CO;2

[50] Strahler, A.N. (1952) Dynamic Basis of Geomorphology. Geological Society of America Bulletin, 63, 923-938.

https://doi.org/10.1130/0016-7606(1952)63[923:DBOG]2.0.CO;2 